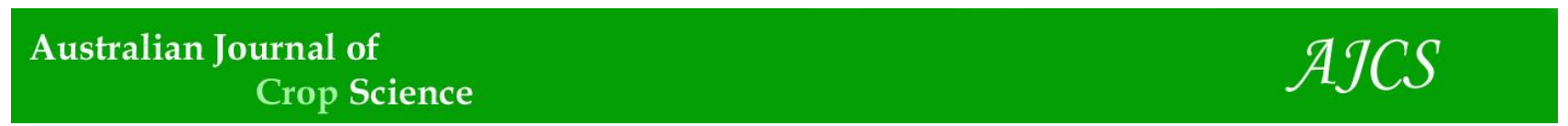

AJCS 14(09):1533-1540 (2020)

ISSN:1835-2707

doi: 10.21475/ajcs.20.14.09.p2773

\title{
Agronomic performance of maize and Brachiaria grasses cultivated at monocropping and intercropping in a compacted Latossolo
}

\section{Aline Borges Torino, Lucas Freitas do Nascimento Júnior, Marlete Ferreira de Brito, Jordaanny Danyelly Pereira Lima, Wainer Gomes Gonçalves, Kátia Aparecida de Pinho Costa, Eduardo da Costa Severiano*}

Federal Institute of Education, Science and Technology of Goias, Rio Verde Campus, Rod, Sul Goiana Km 01, Cx. P. 66, CEP 75.901-970, Rio Verde, Goias, Brazil

*Corresponding author: eduardo.severiano@ifgoiano.edu.br

\begin{abstract}
Obtaining adequate yields by intercropping maize and grasses in soils with poor physical quality is a challenge for managing croplivestock systems in the Cerrado region. The aim of the present study was to verify the viability of maize in intercropping with Brachiaria grasses in the second crop season in a physically degraded Latossolo. The experiment was carried out in accordance with a split-plot completely randomized block design with four replications. Seven treatments $(T)$ were evaluated in the plots: Brachiaria brizantha cv. Paiaguas (p), Brachiaria brizantha cv. Xaraes (x), Brachiaria ruziziensis ( $\mathrm{r}$ ) and maize $(\mathrm{m})$ as monocrops (Tp1, Tx1, Tr1 and Tm1) and maize in intercropping with each of the three Brachiaria species (Tp2, Tx2 and Tr2). Two grass management systems were evaluated in each subplot: with (M1) and without simulated grazing (M2) of the grasses. Soil physical quality was estimated by the least limiting water range of undisturbed soil samples collected at layers of 0-0.05, 0.05-0.10 and 0.10-0.20 m. Crop agronomic yield evaluations were carried out for maize, and both the forage biomass and mulch biomass of the grasses were evaluated. Water deficit during the reproductive crop phase and soil compaction explained the low productivity observed in the experiments. The replacement of the maize crops with pasture during the second crop season is indicated in physical degradation soil conditions. Use of the Brachiaria ruziziensis grass in the intercropping system under simulated pasture grazing resulted in a satisfactory forage yield in the off-season and was the best alternative for oversowing in the intercropping systems. Mulch biomass production in intercropping systems with simulated grazing did not reach adequate amounts for soil cover, and suppression of the last cut could potentially result in increased biomass accumulation and system viability. Overall, it is recommended that maize cultivation during the second crop season in Brazil be preceded by a soil compaction diagnosis.
\end{abstract}

Keywords: soil compaction, crop-livestock integration, soil penetration resistance, second crop season.

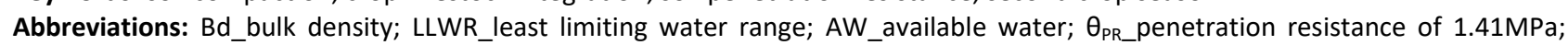
Bdc_critical bulk density; $\theta_{\mathrm{FC}}$ field capacity; P3779H_maize hybrid; DAS_days after sowing; Aw_Tropical Wet climate; T_ treatments; p_Paiaguas; $x_{-}$Xaraes; r_ruziziensis; M_management cut simulation in grasses; V5_five-leaf crop stage; $\Psi_{\mathrm{m}} \_$matric potential; h_hours; R2_grain-filling phase; NWF_non-woven fabric; TP_total porosity; $\theta$ _volumetric water content; PR_penetration

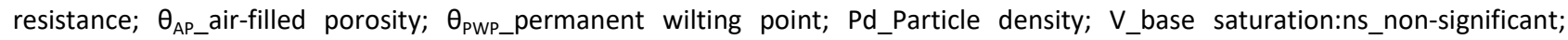
PH_Plant height; ElH_Ear Insertion Height; SD_Stalk Diameter; EL_Ear Length; ED_Ear diameter; NGE_Number of Grains per Ear; W1000_Weight of 1,000 grains; Y_Yield; ND_Not Determined

\section{Introduction}

Brazil's position as a major world agricultural power is due in part to the incorporation of intensive techniques related to the use of inputs and the implementation of mechanized operations in crop production processes (Severiano et al., 2013). However, the use of increasingly larger and heavier machines associated with agricultural modernization has increased the amount of land affected by soil compaction, which was previously a secondary problem (Reichert et al., 2007). In addition, monocropping systems allied to inadequate cultural practices, such as traffic from heavy agricultural machinery in non-ideal soil moisture conditions, promote decreases in soil quality and the consequent degradation of natural resources.

Maize intercropping with grass forage species belonging to the Brachiaria (Trin.) Griseb. genus (syn. Urochloa P. Beauv.) has been used for the recovery of degraded soils because grasses exhibit vigorous, deep and abundant root systems (Flávio Neto et al., 2015). Other Brachiaria benefits include adequate bromatological composition, animal acceptability, fast establishment even when sown late, increased growth throughout the whole dry season and high desiccation efficiency (Machado and Valle, 2011), and it also can be used for mulch biomass in no tillage systems (Kichel et al., 2009). Brazil is currently the third largest maize producer. Most of the production, mainly in the Central-West region, is concentrated in the second crop season (Conab, 2016). This favours grass sowing as part of intercropping systems and results in "third and fourth crops" during the agricultural year. These crops are characterized as pastures after maize in the second crop season, and they can be used as mulch biomass, which can be obtained by desiccating the remaining pasture to form soil cover. However, the climate in the Brazilian Cerrado 
region is characterized by a prolonged dry season, which may hinder forage production systems in intercropping with annual crops (Pacheco et al., 2008).

Achieving adequate yields of maize in intercropping in the second crop season, coupled with satisfactory forage production in the off-season, is a challenge for managing production systems in the Cerrado region. In this context, the aim of the present study was to verify the viability of maize in intercropping with different grass species belonging to the Brachiaria genus during the second crop season in a compacted Latossolo Vermelho.

\section{Results and Discussion}

\section{Soil physical quality}

The relationship between water content and bulk density (Bd) with respect to the critical least limiting water range (LLWR) limits is presented in Figure 2. The LLWR is defined at the upper limit as the field capacity, and the lower limit is the penetration resistance when the $B d$ is $>1.14 \mathrm{~kg} \mathrm{dm}^{-3}$. Up to this point, the LLWR is equal to the available water $\left(A W=\theta_{F C}-\right.$ $\theta_{\text {PWP }}$.

This phenomenon is similar to that observed by Severiano et al. (2011), whose LLWR amplitude in Cerrado soils had an upper limit of the water content at field capacity and had penetration resistance as the lower limit. These authors considered the granular Latossolo structure as the factor that favours greater LLWR restriction by penetration resistance $\left(\theta_{\mathrm{PR}}\right)$, since the latter leads to greater structural pore development (macropores) that, in turn, promote low capillarity, reduced water retention and, consequently, reduced soil particle lubrication and root friction. $\theta_{\mathrm{AP}}$ was not a limiting factor in the present study, which could be attributed to the high total porosity present in Latossolos (Figure 2).

The critical bulk density (Bdc), where the LLWR is equal to zero, was $1.29 \mathrm{~kg} \mathrm{dm}^{-3}$ in the evaluated layer. The Bdc value of the LLWR was lower in the present study compared to that reported by Freddi et al. (2009b), which was $1.46 \mathrm{~kg} \mathrm{dm}^{-3}$ in a medium-texture Red Latosol considering a penetration resistance of $1.65 \mathrm{MPa}$, and similar to that reported by Kaiser et al. (2009), which was $1.36 \mathrm{~kg} \mathrm{dm}^{-3}$ in a clayey Red Latosol with a $1.5 \mathrm{MPa}$ penetration resistance, similar to the suggested value for maize (the proposed value is presented in Table 2). The idea to consider limits for the LLWR from research results available in the literature, which was applied here in terms of the penetration resistance of maize crops, indicates progress in the use of improved methods compared to the use of fixed values that do not consider the soil compaction tolerance of different cultivated species. Table 2 shows that there is little variation between studies, and the values generally lower than 2.0 MPa.

Considering the values in the literature along with the results of the LLWR modelling carried out herein (Figure 2), it is suggested that maize has a very low tolerance to soil compaction, especially under adverse climatic conditions that reduce soil water availability during the crop cycle. It is important to note the LLWR is 0 throughout the soil profile for the maize crop (Figure 3) since the $\theta_{\mathrm{PR}}$ exceeded the field capacity values $\left(\theta_{\mathrm{FC}}\right)$. According to Gonçalves et al. (2014), it is possible that plant root systems can be entrapped within a reduced soil volume within the planting groove (the so-called "potting effect"), resulting in crop yield losses. This fact is more obvious in years with irregular rain distribution due to limited access to water stored in the deep layers.

An overlap of the lower and upper LLWR limits was detected, demonstrating that the mean Bd of the layers was higher than the Bdc of $1.29 \mathrm{~kg} \mathrm{dm}^{-3}$ (Table 3). Thus, even if the water content always remained at field capacity (which was not true, especially in second crop seasons), restrictions due to the PR would occur.

Therefore, $\theta_{\mathrm{PR}}$ is the most limiting factor for LLWR in Brazilian Cerrado soils (Severiano et al., 2011), and defining the limiting values may improve the applicability of this soil physical quality indicator in evaluations of agronomic yield. Until the proposed additions related to the critical limit are implemented proposed advances related to the critical limit, an alternative with immediate effects would be to consider reference values available in the literature and associated with crops of interest for LLWR determinations, as carried out herein. Considering collaborations made available in recent years in the literature for maize cultivation in Brazil (Table 2), it should be noted that the mean PR value was $1.41 \mathrm{MPa}$ (ranging from 0.9 to 2.15 ) according to the experimental conditions of each study.

\section{Maize yield}

The results indicate that the cultivation systems did not influence maize development in the second crop season (Table 4), since there were no changes in maize characteristics between the intercropping systems and monocropping systems. Oversowing the grass at 22 days after maize sowing may have promoted a noncompetitive intercropping effect. Bravin and Oliveira (2014) observed that maize intercropping with Xaraes palisadegrass did not lead to competition with the maize crop, evidencing a decrease in grass competitiveness when sown after maize and slowing the initial grass establishment.

Considering the maize hybrid in question $(\mathrm{P} 3779 \mathrm{H})$, the agronomic variables related to vegetative development (plant height, ear insertion height and shoot diameter) exhibited satisfactory initial development (Table 4) (Bravin and Oliveira, 2014). This is probably due to the favourable microenvironment for root development in the sowing furrow. When studying the physical properties of a Latosol, Anghinoni et al. (2017) verified that furrow opening by discs led to loosening of the soil within the line of plants, favouring plant growth during the crop cycle. In addition, satisfactory amounts of rainfall during the vegetative growth period (Figure 1), which occurred from January to March, contributed to maize establishment. These results suggest that soil compaction may not be the main limiting factor for agricultural production under regular rainfall conditions (such as those normally occurring during the first crop season).

However, maize yields not only were strongly associated with the water stress (Table 4) to which the crop was subjected during the full flowering phase (Figure 1) but also were aggravated by limitations to deep root penetration imposed by soil compaction, corroborating the findings reported by Freddi et al. (2007a).

Assessing the LLWR effects on maize yields, Li et al. (2020) found that these effects are an effective indicator of the physical properties of the soil and that precipitation should be considered when evaluating their relationship with maize yield, which is applicable in our study. The results reported herein undoubtedly reinforce the fact that in southwestern Goias and in the second crop season of 2016 (at the same time 
the experiment was conducted), this hybrid produced crop yields up to 3.5-fold higher than those observed in the physically degraded experimental area (Pioneer, 2018).

It is common to attribute low yields exclusively to water deficit, neglecting the limitations imposed by soil compaction. Thus, it should be noted that yield decreases can occur even under favourable climatic conditions if the water deficit occurs during the critical period, which is between the pre-flowering stage and the beginning of grain filling; this is because reproductive capacity recovery cannot occur satisfactorily considering that the reproductive phase of the crop plants occurs faster than the vegetative phase (Bergamaschi et al., 2006).

The maize yields were also not influenced by intercropping (absence of grass competition) (Table 4), corroborating the reports published by Bravin and Oliveira (2014), who did not observe a decrease in maize yields when maize was intercropping with different Brachiaria grasses compared with those when maize was grown as a monocrop. Sowing in the second crop season in this study was applied at the proper time according to the data of CONAB (2016), the agency responsible for Brazilian agricultural monitoring. In terms of climatic risk, January to March was indicated as a favourable period, and this preventative measure should become a part of rural planning to minimize the recurrence of agricultural insurance.

However, maize yield estimates in the second crop season in Goias state, Brazil, were registered as having an mean yield of $3,537 \mathrm{~kg} \mathrm{ha}^{-1}$ for 2016, which was considered the largest decrease in the last 10 years due to the hot summers, which corresponded to the ear-formation stage (Conab, 2016). The yield obtained in this work was, on mean, $2,526 \mathrm{~kg} \mathrm{ha}^{-1}$, which is $29 \%$ lower than the regional mean. Similar results were reported by Freddi et al. (2007a), indicating that physical restrictions resulting from soil compaction and low water availability during the vegetative growth period caused morphological changes in the maize root system, restricting nutrient absorption and limiting grain yields. According to Kaiser et al. (2009), plants tend to maintain superficial root systems when they find adequate growth conditions at the beginning of the vegetative period or when they are under conditions of strong penetration resistance. Under these conditions, access to water stored in deep layers is restricted due to increased resistance to root penetration.

It has been suggested that water deficit is not the only determining factor for the yield decrease during the second crop season in the Central-West Region of Brazil. According to Brazilian crop monitoring carried out by CONAB (2016) and due to the strong drought (the most severe in southwestern Goias), several areas produced maize ears whose developmental pattern was well below the normal pattern, with low and uneven numbers of grains. Adequate rainfall distribution can minimize soil compaction effects. This is the main factors that farmers neglect, as they do not consider proper soil and water management or conservation and ignore the need to implement environmental mitigation practices, such as agricultural and livestock integration (Flávio Neto et al., 2015).

\section{Forage biomass and mulch biomass yield}

As monocropping, Paiaguas and Xaraes palisadegrass presented increased yields at 64 and 128 DAS but decreased yields at the last two simulated grazing cuts [190 and 259 days after sowing (DAS); Table 5]. These data corroborate those reported by Costa et al. (2016b), who reported a $65 \%$ decrease in Paiaguas grass yield in monocropping the offseason. However, Brachiaria grasses showed satisfactory agronomic performance even under physically degraded soil conditions, corroborating the results of Maia et al. (2014). In this sense, when the total yield of each system was observed (Table 5), the highest means were observed in the grass monocropping systems. In general, the results indicate that the Xaraes palisadegrass in monocropping system presented the highest forage yields, while the intercropping systems presented lower mean yields. The edaphoclimatic and management conditions may have influenced these results, since oversowing under compact soil conditions forms an unfavourable environment for the establishment of the third crop in agriculture-livestock integration systems. With respect to the simulated grazing cut, the Xaraes palisadegrass in the monocropping system presented the highest mulch biomass yield (Table 6), followed by Brachiaria ruziziensis in the monocropping system; similar results were reported by Machado and Assis (2010). The higher mulch biomass production by Xaraes palisadegrass can be attributed to high dry matter yield, especially that of the leaves, as well as its rapid regrowth. The oversowing adopted in the present study was associated with water deficit during the growing season of the grasses (Figure 1), which may be the cause of low mulch biomass production in intercropping system compared with the monocropping system (Table 6). When evaluating the mulch biomass of Brachiaria brizantha in an intercropping system and when cultivated in the second crop season, Costa et al. (2016a) verified that the production was lower in the oversowing treatment ( 15 days after annual crop sowing) than in the other treatments. The highest mulch biomass was obtained in the absence of cutting in all evaluated systems (no-till management system simulations; Table 6). In the no-till management system simulation, in which there was no cutting, the highest mulch biomass yields were achieved by the Xaraes and Paiaguas palisadegrass in monocropping systems (Table 6). This corroborates the results of Machado and Assis (2010), who observed greater mulch biomass for Xaraes palisadegrass in monocropping (9437 kg ha-1) compared to the other grasses studied and in the absence of cutting. The relatively high rainfall (Figure 1 ) during the initial months and the absence of periodic foliage removal may have contributed to the increased biomass accumulation during grass development. The mulch biomass in the grazing simulation treatments (Table 6) did not reach the reference value of $6,000 \mathrm{~kg} \mathrm{ha}^{-1}$ on the soil surface; according to Alvarenga et al. (2001), this value can be considered an adequate amount for no-tillage systems and favours a good soil cover rate. With respect to the mulch biomass yield, the fourth crop of the agricultural period evaluated herein presented an unsatisfactory performance concerning the simulated grazing management, mainly in the intercropping systems. These results can be attributed mainly to the severe conditions during the summer (Figure 1), since soil compaction does not seem to be the main limiting factor for the development of Brachiaria grasses (Flávio Neto et al., 2015; Maia et al., 2014). It is thus suggested that the suppression of the last cut may increase biomass accumulation, leading to vigorous regrowth for desiccation ultimately to achieve the adequate mulch biomass soil cover amount, allowing for viable intercropping.

It is therefore necessary to continue studies on climate-soilplant-animal interrelationships in agriculture-livestock integration systems in the Cerrado region to sustain the 
Table 1. Physical and chemical characterization of the Latossolo Vermelho Acriférrico típico in Rio Verde-GO, obtained from the 0$0.20 \mathrm{~m}$ layer.

\begin{tabular}{|c|c|c|c|c|c|}
\hline $\begin{array}{l}\mathrm{Pd}^{(1)} \\
\left(\mathrm{kg} \mathrm{dm}^{-3}\right)\end{array}$ & Sand & $\begin{array}{l}\text { anulomet } \\
\text { Silt } \\
\left(\mathrm{g} \mathrm{kg}^{-1}\right)\end{array}$ & Clay & $\begin{array}{l}\mathrm{V}^{(3)} \\
\%\end{array}$ & $\mathrm{pH}^{(4)}$ \\
\hline 2.74 & 350 & 200 & 450 & 61.3 & 5.4 \\
\hline $\begin{array}{l}\mathrm{Ca} \\
\left(\mathrm{cmol}_{\mathrm{c}} \mathrm{dm}^{-3}\right)\end{array}$ & $\mathrm{Mg}$ & $\mathrm{H}+\mathrm{Al}$ & $\mathrm{K}$ & $\begin{array}{c}P^{(5)} \\
\left(\mathrm{mg} \mathrm{dm}^{-3}\right)\end{array}$ & $\mathrm{Zn}$ \\
\hline 2.1 & 1.3 & 2.3 & 97 & 1.2 & 2.3 \\
\hline
\end{tabular}

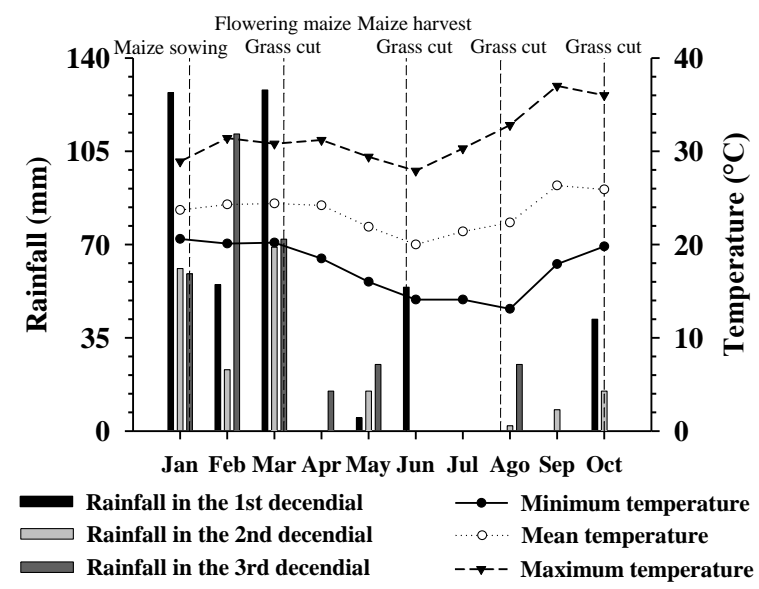

Fig 1. Rainfall $(\mathrm{mm})$ and temperature (으) during the experiment carried out in the municipality of Rio Verde-GO, 2016.

Table 2. Means of the critical soil penetration resistance (PR) values in $M P a$ for maize development.

\begin{tabular}{lcccc}
\hline PR (MPa) & Type of soil & Clay $\left(\mathrm{g} \mathrm{kg}^{-1}\right)$ & Cultivation system & Reference \\
\hline 0.91 & Red-Yellow Argisol & 70 & Conventional & Beutler et al. (2009) \\
1.53 & Yellow Argisol & 90 to 140 & Conventional & Deperon Junior. et al. (2016) \\
1.40 & Red Latosol & 340 & Vase & Foloni et al., (2003) \\
1.16 & Red Latosol & 323 & Conventional & Freddi (2007) \\
1.65 & Red Latosol & 323 & Conventional & Freddi et al. (2007)a \\
1.65 & Red Latosol & 323 & Conventional & Freddi et al. (2007)b \\
2.15 & Red Latosol & 210 & Conventional & Freddi et al. (2009)a \\
$1.23-1.43$ & Red Latosol & 323 & Conventional & Freddi et al. (2009)b \\
1.00 & Diversified soils & 58 to 374 & Conventional & Silva et al., (2004) \\
1.41 & & & Means & \\
\hline
\end{tabular}

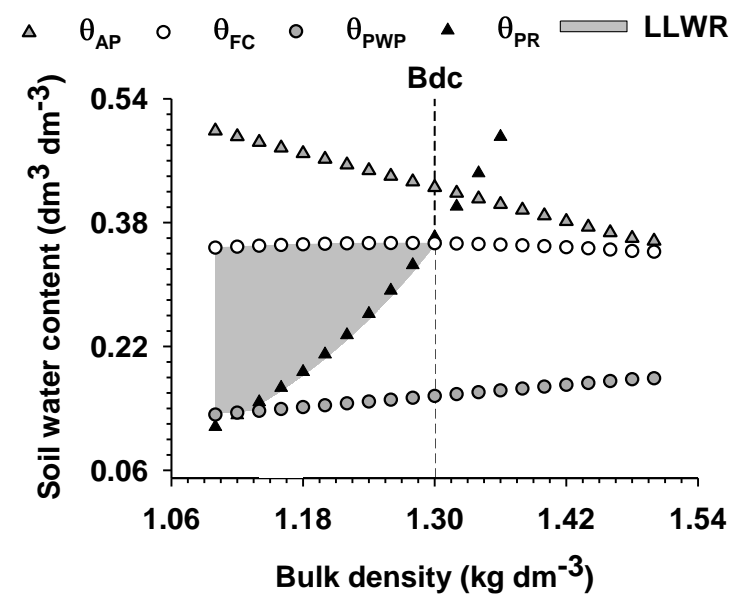

Fig 2. Soil water content $(\theta)$ variation with bulk density increments $(B d)$ at the critical limits of air-filled porosity of $0.10 \mathrm{~m}^{3} \mathrm{~m}^{-3}\left(\theta_{\mathrm{AP}}\right)$,

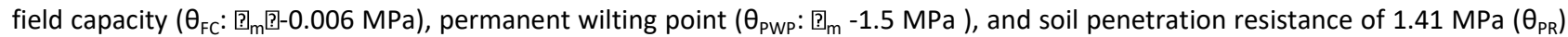
of the evaluated Latossolo Vermelho Acriférrico típico in the 0-0.20 m layer, cultivated with maize via monocroping and intercropping with Brachiaria grass. The filled area represents the LLWR. Bdc: critical bulk density to plant development. 
Table 3. Summary of the analysis of variance carried out for bulk density (Bd) in $\mathrm{kg} \mathrm{dm}^{-3}$ at different depths in Latossolo Vermelho Acriférrico típico cultivated with maize via monocropping and intercropping with Brachiaria grasses, Rio Verde, Goias, Brazil.

\begin{tabular}{|c|c|c|c|}
\hline \multirow[b]{2}{*}{ Variation source } & \multicolumn{3}{|c|}{ Square means } \\
\hline & $\begin{array}{c}\mathrm{Bd}^{\mathrm{ns}} \\
(0-0.05 \mathrm{~m})\end{array}$ & $\begin{array}{c}\mathrm{Bd}^{\mathrm{ns}} \\
(0.05-0.10 \mathrm{~m})\end{array}$ & $\begin{array}{c}\mathrm{Bd}^{\mathrm{ns}} \\
(0.1-0.20 \mathrm{~m})\end{array}$ \\
\hline Crop systems & 0.0015 & 0.0009 & 0.0008 \\
\hline Residue & 0.0012 & 0.0006 & 0.0004 \\
\hline CV (\%) & 2.59 & 1.94 & 1.60 \\
\hline General means & 1.32 & 1.30 & 1.30 \\
\hline
\end{tabular}

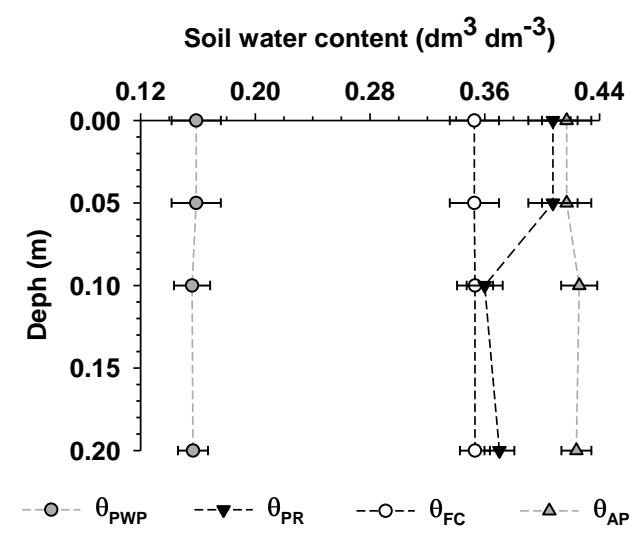

Fig 3. Soil water content $(\theta)$ variation at different depths for the critical limits of penetration resistance $\left(\theta_{\mathrm{PR}}\right)$, permanent wilting point $\left(\theta_{\mathrm{PWP}}\right)$, field capacity $\left(\theta_{\mathrm{FC}}\right)$ and air-filled porosity of $0.10 \mathrm{~m}^{3} \mathrm{~m}^{-3}\left(\theta_{\mathrm{AP}}\right)$ of the evaluated Latossolo Vermelho Acriférrico típico cultivated with maize in second crop season. LLWR was null throughout the soil profile.

Table 4. Summary of the analysis of variance for the agronomic variables and maize yield cultivated during the second crop season in monocropping and intercropping with Brachiaria grasses in a Latossolo Vermelho Acriférrico típico under soil compaction evaluated in Rio Verde-GO, 2016.

\begin{tabular}{|c|c|c|c|c|c|c|c|c|}
\hline \multirow[b]{2}{*}{ Variation source } & \multicolumn{8}{|c|}{ Square means } \\
\hline & $\begin{array}{l}\mathrm{PH}^{\mathrm{ns}} \\
(\mathrm{m})\end{array}$ & $\begin{array}{l}\mathrm{EIH}^{\mathrm{ns}} \\
(\mathrm{m})\end{array}$ & $\begin{array}{l}\mathrm{SD}^{\mathrm{ns}} \\
(\mathrm{mm})\end{array}$ & $\begin{array}{l}E L^{\mathrm{ns}} \\
(\mathrm{mm})\end{array}$ & $\begin{array}{l}E D^{\mathrm{ns}} \\
(\mathrm{mm})\end{array}$ & $N G E^{\text {ns }}$ & $\begin{array}{l}\text { W1000 ns } \\
\text { (g) }\end{array}$ & $\begin{array}{c}\mathrm{Y}^{\mathrm{ns}} \\
\left(\mathrm{kg} \mathrm{ha}^{-1}\right)\end{array}$ \\
\hline Cultivation system & 0.0022 & 0.0002 & 0.9620 & 33.8847 & 1.5345 & $3,940.41$ & 3.0167 & $145,997.47$ \\
\hline Residue & 0.0046 & 0.0033 & 1.2313 & 135.0056 & 4.8706 & $4,485.36$ & 2.5273 & $319,446.13$ \\
\hline CV (\%) & 3.77 & 6.28 & 4.36 & 6.35 & 4.97 & 13.01 & 17.46 & 22.37 \\
\hline General means & 1.80 & 0.92 & 25.43 & 182.95 & 44.44 & 515 & 91.07 & $2,526.28$ \\
\hline
\end{tabular}

Table 5. Forage yield $\left(\mathrm{kg} \mathrm{ha}^{-1}\right)$ of Brachiaria grasses according to cultivation in monocropping and intercropping with maize and cut interval in the Latossolo Vermelho Acriférrico típico evaluated in Rio Verde, Goias, Brazil.

\begin{tabular}{|c|c|c|c|c|c|}
\hline \multirow{2}{*}{ Forage system } & \multicolumn{4}{|c|}{ Cut interval } & \multirow{2}{*}{ Total } \\
\hline & 64 DAS & 128 DAS & 190 DAS & 259 DAS & \\
\hline B. brizantha cv. Paiaguas in monocropping & $3033 \mathrm{Ab}$ & $3391 A a^{(1)}$ & 1067Bab & 1271Bab & 8762 \\
\hline B. brizantha cv. Paiaguas in intercropping ${ }^{(2)}$ & ND & $167 \mathrm{Bc}$ & $491 \mathrm{ABC}$ & 756Aab & 1414 \\
\hline B. brizantha cv. Xaraes in monocropping & $3073 \mathrm{Ab}$ & 3036Aa & 1366Ba & 1467Ba & 8942 \\
\hline B. brizantha cv. Xaraes in intercropping & ND & $301 B c$ & $588 \mathrm{ABbc}$ & 957Aab & 1846 \\
\hline B. ruziziensis in monocropping & $5585 \mathrm{Aa}$ & $1497 \mathrm{Bb}$ & 970Babc & 923Bab & 8975 \\
\hline B. ruziziensis in intercropping & ND & 692Abc & 926Aabc & $677 A b$ & 2295 \\
\hline
\end{tabular}

Table 6. Mulch biomass of Brachiaria grasses in monocropping and intercropping with maize cultivated during the second crop season and management with and without grazing simulation cut in Latossolo Vermelho Acriférrico típico in Rio Verde, Goiás, Brazil.

\begin{tabular}{|c|c|c|}
\hline \multirow[b]{2}{*}{ Forage system } & \multicolumn{2}{|c|}{ Management } \\
\hline & $\begin{array}{l}\text { With cut } \\
\left(\mathrm{kg} \mathrm{ha}^{-1}\right)\end{array}$ & $\begin{array}{l}\text { Without cut } \\
\qquad\left(\mathrm{kg} \mathrm{ha}^{-1}\right)\end{array}$ \\
\hline B. brizantha cv. Paiaguas in intercropping & $1916 \mathrm{cB}^{(1)}$ & $6083 c A$ \\
\hline B. brizantha cv. Paiaguas in monocropping & 2957abcB & $18496 a A$ \\
\hline B. brizantha cv. Xaraes in intercropping & $2839 a b c B$ & $8217 \mathrm{bA}$ \\
\hline B. brizantha cv. Xaraes in monocropping & $4736 a B$ & $18563 a A$ \\
\hline B. ruziziensis in intercropping & $2580 \mathrm{bcB}$ & $8504 b A$ \\
\hline B. ruziziensis in monocropping & 4060abB & $9761 \mathrm{bA}$ \\
\hline
\end{tabular}


establishment of up to four crops without the use of supplementary irrigation (first summer crop, second grain crop, third crop of grazing forage and fourth crop of mulch biomass under no tillage).

\section{Materials and Methods}

\section{Experimental area characteristics}

The experiment was conducted in the municipality of Rio Verde, Goias, Brazil, $17^{\circ} 48^{\prime} 34.25$ "S and $50^{\circ} 54^{\prime} 05.36^{\prime \prime} \mathrm{W}$, at an altitude of $731 \mathrm{~m}$. The region's climate is classified as tropical wet $(A w)$ according to the Köppen classification, with dry winters and rainy summers. The annual mean temperature of the region is $25{ }^{\circ} \mathrm{C}$, and the annual rainfall is approximately $1,600 \mathrm{~mm}$, with the predominant rainy season occurring between November and April. The "summer" climatic phenomenon occurs in the middle of the rainy season, normally lasting 10 to 15 days and sometimes lasting for more than 30 days. The soil of the experimental area is characterized as a Latossolo Vermelho Acriférrico típico (according Santos et al. 2018; an Oxisol according to U.S. Soil Taxonomy; or a Ferralsol according to the World Reference Base for Soil Resources) with a clayey textural class whose physical properties (Table 1) were determined according to the methods of Teixeira et al. (2017).

The rainfall and temperature were monitored during the experiment. The results are displayed in Figure 1.

\section{Experimental design}

Prior to the installation of the experiment, soil samples were collected at 0-0.20 m depth for soil physico-chemical analyses. Two cross-sub-soiling operations were carried out at a depth of $0.40 \mathrm{~m}$, with one ploughing and two harrowings performed to eliminate possible mechanical impedance of the preestablished layers. Fifteen days before the experiment, glyphosate herbicide was applied at $5.0 \mathrm{~L} \mathrm{ha}^{-1}$ for chemical weed control of the soil seed bank.

Soil compaction was applied by traffic from an agricultural tractor with a tare weight of $4.5 \mathrm{Mg}$. The wheels included two front tires (diagonal) and two rear tires with the following technical specifications: front, from 14.9"-24.0"; rear, 18.4"34.0"; inflation pressures of 95 and $165 \mathrm{kPa}$, respectively. Traffic intensity comprised four tractor passes in the same place, encompassing the entire soil surface of the experimental plots, and traffic was applied when the soil water content was close to field capacity, which was caused by rainfall before the test was established in January, in accordance with the procedures described by Gonçalves et al. (2014).

Seven treatments $(\mathrm{T})$ were evaluated in the plots: Brachiaria brizantha cv. Paiaguas ( $\mathrm{p})$, Brachiaria brizantha cv. Xaraes (x), Brachiaria ruziziensis $(r)$ and maize $(m)$ as monocrops (Tp1, $\operatorname{Tx} 1, \operatorname{Tr} 1$ and $\operatorname{Tm} 1$ ) and maize in intercropping with each of the three Brachiaria species (Tp2, Tx2 and Tr2). Two grass management systems were evaluated in each subplot: with (M1) and without simulated grazing (M2) of the grasses. The plot dimensions were $14.0 \mathrm{~m}$ in length and $4.5 \mathrm{~m}$ in width, and the plots consisted of nine rows spaced $0.50 \mathrm{~m}$ apart. The five central lines were considered areas of interest, excluding 1.0 $\mathrm{m}$ from each end of the plot. The intercropping systems with simulated forage cutting represent crop scenarios in which the third grazing produced a forage crop and the fourth crop produced mulch biomass for no tillage; these were implemented after the second crop season. The grasses in monocropping with simulated forage cutting represent scenarios in which pastures are grown for mulch biomass. On the other hand, the grass systems without simulated cutting represent scenarios with free growth in the off-season, which is destined exclusively for mulch biomass.

Mechanical maize sowing was carried out on January 26, 2016, using an MF 510 double-disc seeder and the Pioneer hybrid $\mathrm{P} 3779 \mathrm{H}$, and fertilizer was applied at $30 \mathrm{~kg} \mathrm{ha}^{-1} \mathrm{~N}, 200 \mathrm{~kg} \mathrm{ha}^{-1}$ $\mathrm{P}_{2} \mathrm{O}_{5}$ and $40 \mathrm{~kg} \mathrm{ha}^{-1} \mathrm{~K}_{2} \mathrm{O}$, as recommended by Sousa and Lobato (2004). The soil analysis results are presented in Table 1. The nutrient sources included urea, simple superphosphate and potassium chloride.

Manual sowing of the grasses in monocropping was carried out on January 27, 2016. Fertilization was carried out in the same way as that for maize cultivation. The sowing rate was $9.0 \mathrm{~kg} \mathrm{ha}^{-1}$ of pure and viable seed to achieve a final population stand of $17 \pm 1$ plants $\mathrm{m}^{-2}$.

The maize plants were thinned to fit reach the population density of 60,000 plants $\mathrm{ha}^{-1}$ (three plants per metre) at 22 DAS at the five-leaf stage (V5). At this time, grass oversowing was carried out in the intercropping plots with a seed/fertilizer mixture such that $70.0 \mathrm{~kg} \mathrm{ha}^{-1} \mathrm{~N}$ and $30.0 \mathrm{~kg} \mathrm{ha}^{-1} \mathrm{~K}_{2} \mathrm{O}$ from ammonium sulfate and potassium chloride sources, respectively, were applied, aiming for the same population density target described above.

\section{Sampling and evaluation of soil physical properties}

After sowing, three undisturbed soil samples were collected from between the lines of plants with the aid of a Uhland-type sampler in each experimental plot, corresponding to the three sampling layers $(0-0.05,0.05-0.10$ and $0.10-0.20 \mathrm{~m})$. The volumetric sampling rings were $6.4 \mathrm{~cm}$ in diameter and $5.0 \mathrm{~cm}$ in height. Samples were also collected at the described depths to estimate the permanent wilting point [-1.5 MPa matric potential $\left(\psi_{\mathrm{m}}\right)$ ] using a Richards extractor (Teixeira et al., 2017).

In the laboratory, the excess soil on the edges of the volumetric rings was removed, and the samples were saturated with distilled water $(48 \mathrm{~h})$. They were subsequently subjected to a $\psi_{\mathrm{m}}$ of $-0.006 \mathrm{MPa}$ until reaching hydraulic equilibrium. Thus, the obtained water content was considered equivalent to the soil field capacity (Teixeira et al., 2017).

Different water contents, ranging from 0.05 to $0.36 \mathrm{dm}^{3} \mathrm{dm}^{-3}$, were subsequently applied to each sample for a penetrometry test according to the methods of Severiano et al. (2011). The samples were then dried in an oven at $105^{\circ} \mathrm{C}$ for 48 hours to determine the Bd. The total porosity (TP) was determined by Equation 1, where $P d$ is the particle density, as follows: $T P=$ $[1-(B d / P d)]$.

A penetration resistance curve was generated fiting the penetration resistance (PR) values as a function of the volumetric water content $(\theta)$ and the $B d$ using the nonlinear model proposed by Busscher (1990) (Equation 2) as follows: $P R=0.097 \vartheta^{-0.959} B d^{6.509}\left(R^{2}=0.83^{* *}\right)$.

The empirical parameters of the penetration resistance curve were obtained by minimizing the sum of squares of the difference between the determined and estimated values, according to the methods of Leão and Silva (2004). To evaluate the accuracy of the adjusted model, the root of the mean square error between the determined values was considered, and the coefficient of determination of each adjustment was estimated $\left(R^{2}\right)$. 
The physical quality of the soil was determined by its least limiting water range according to the procedures described by Silva et al. (1994), considering the upper limits equal to the soil water content at $\theta_{\mathrm{FC}}\left(\psi_{\mathrm{m}}=-0.006 \mathrm{MPa}-\theta_{\mathrm{FC}}\right)$ (Severiano et al., 2011) and/or the air-filled porosity $\left(\theta_{\mathrm{AP}}\right)$ equal to $0.10 \mathrm{dm}^{3}$ $\mathrm{dm}^{-3}$ of the total porosity (TP), the latter of which was calculated for each sample according to Equation 3 as follows: $\vartheta_{A P}=T P-0.1$.

Concerning the lower LLWR limits, the water retained at -1.5 $\mathrm{MPa}$ was considered the permanent wilting point $\left(\theta_{\mathrm{PWP}}\right)$ and/or the water content corresponding to a penetration resistance of $1.41 \mathrm{MPa}\left(\theta_{\mathrm{PR}}\right)$, considering the mean critical values for maize reported in previous studies (Table 2) and determined according to Equation 2.

The LLWR was obtained by adjusting the soil water content limits as a function of $\mathrm{Bd}$, with the upper limit being the lowest value between $\theta_{\mathrm{FC}}$ and $\theta_{\mathrm{AP}}$ and the lower limit and with the highest value between $\theta_{\mathrm{PWP}}$ and $\theta_{\mathrm{PR}}$, via Sigma Plot 11.0 software.

\section{Crop evaluations}

At 84 DAS, at which time the maize ears were covered with nonwoven fabric (NWF) (milky grain), morphological development was evaluated for 10 plants from each plot, considering the following variables: plant height at the point of insertion of the height of the last leaf $(\mathrm{PH})$, maize ear insertion height $(\mathrm{EIH})$ and stalk diameter at the second internode above the soil (SD).

Maize was harvested at 126 DAS, and the yield was evaluated as the grain weight with a moisture correction of $13 \%$. Ten whole plants of each harvested plot were used for evaluations of the following variables: ear length (EL) and diameter (ED), number of grains per ear (NGE), weight of 1,000 grains (W1000) and the harvest index, corresponding to the grain fraction in relation to the dry matter of the aerial portion of the plants. The grasses were monitored for 259 DAS for their biomass increases and were maintained at a grazing height of $0.20 \mathrm{~m}$, with cut intervals corresponding to 65 days, on mean. Four evaluations of the forage yield to pasture simulation in the monocopped grasses were performed, carried out on March 31, June 03, August 04 and October 10, 2016 (4 $4^{\text {th }}$ cut). In the intercropping systems, the first cut took place after June 03, 2016, after the maize crop harvest, and there were a total of three cuts. Forage yield was determined through the collection of forage samples within a $1.0 \mathrm{~m}^{2}$ area with the aid of a metal square at a reference height of $0.20 \mathrm{~m}$ in relation to the soil surface. The cut material was weighed, and a subsample (approximately $0.5 \mathrm{~kg}$ ) was placed in a forcedcirculation air oven at $55{ }^{\circ} \mathrm{C}$ for 72 hours, after which the amount was extrapolated to $\mathrm{kg} \mathrm{ha}^{-1}$. After each evaluation, the grasses in the entire experimental area were cut at the same height and later removed from the area.Desiccation occurred five days after the last cut. The total area was sprayed on October 17, 2016, with glyphosate herbicide at $4.5 \mathrm{~L} \mathrm{ha}^{-1}$. Fourteen days later, the mulch biomass was determined using the same procedure used for the determination of forage, by cutting close to the soil surface.

\section{Statistical analysis}

The results of the evaluated attributes of maize and the forage yields were subjected to an analysis of variance and then to Tukey's test at the level $5 \%$ probability when significant.

\section{Conclusions}

No Brachiaria grass influence on maize agronomic performance or yield between the intercropping system and the monocropping system was detected.

The replacement of maize in the second crop season with grass occurred under a state of physical soil degradation.

Under the study conditions, among the tested species, Brachiaria ruziziensis is the best alternative for oversowing in these intercropping systems.

The fourth crop, which is related to mulch biomass production in the intercropping systems and to simulated grazing, did not produce adequate amounts of biomass for soil cover. The last cut should therefore be suppressed to increase biomass accumulation and system viability.

\section{Conflicts of interest}

The authors declare no financial or other competing conflicts of interest.

\section{Acknowledgments}

The authors would like to thank the Instituto Federal Goiano, for financial support.

\section{References}

Alvarenga RC, Cabezas WAL, Cruz JC, Santana DP (2001) Plantas de cobertura de solo para o sistema plantio direto. Inf Agropec. 22(208):25-36.

Anghinoni G, Tormena CA, Lal R, Moreira WH, Betioli Júnior E, Ferreira CJB (2017) Within cropping season changes in soil physical properties under no-till in Southern Brazil. Soil Till Res. 166:108-112.

Bergamaschi H, Dalmago GA, Comiran F, Bergonci Jl, Müller AG, França S, Santos AO, Radin B, Bianchi CAM, Pereira PG (2006) Déficit hídrico e produtividade na cultura do milho. Pesq Agropec Bras. 41(2):243-249.

Beutler NA, Centurion JF, Mengatto LH, Mengatto LH, Alves JB, Wagner GPC (2009) Impacto do tráfego de máquinas na qualidade física do solo e produtividade de milho em Argissolo. Acta Sci Agron. 31(2):359-364.

Bravin MP, Oliveira TK (2014) Adubação nitrogenada em milho e capim-xaraés sob plantio direto e preparo convencional em sistema agrossilvipastoril. Pesq Agropec Bras. 49(10):762-770.

Busscher WJ (1990) Adjustment of flat-tipped penetrometer resistance data to a common water content. Trans. Am. Soc. Agric. Eng., 33(2):519-524.

Conab - Companhia Nacional de Abastecimento (2016) Acompanhamento da safra brasileira de grãos: décimo segundo levantamento, safra 2015/16, Brasília. 3(12):176 p.

Costa RRGF, Costa KAP, Assis RL, Santos CB, Severiano EC, Rocha AFS, Oliveira IP, Costa PHCP, Souza WF, Aquino MM (2016a) Dynamics of biomass of pearl millet and Paiaguas palisadegrass in different forage systems and sowing periods in yield of soybean. Afr J Agric Res. 11(45):4661-4673.

Costa RRGF, Costa KAP, Santos CB, Severiano EC, Epifanio PS, Silva JT, Teixeira DAA, Silva VR (2016b) Production and nutritional characteristics of pearl millet and Paiaguas palisadegrass under different forage systems and sowing periods in the offseason. Afr J Agric Res. 11(19):1712-1723.

Deperon Júnior MA, Nagahama HJ, Olszevski N, Cortez JW, Souza EB (2016) Influência de implementos de preparo e de 
níveis de compactação sobre atributos físicos do solo e aspectos agronômicos da cultura do milho. Eng Agríc. 36(2):367-376.

Flávio Neto J, Severiano EC, Costa KAP, Guimarães Junnyor WS, Gonçalves WG, Andrade R (2015) Biological soil loosening by grasses from genus Brachiaria in crop-livestock integration. Acta Sci Agron. 37(3):375-383.

Foloni JSS, Calonego JC, Lima SL (2003) Efeito da compactação do solo no desenvolvimento aéreo e radicular de cultivares de milho. Pesq Agropec Bras. 38(8):947-953.

Freddi OS (2007) Avaliação do intervalo hídrico ótimo em Latossolo Vermelho cultivado com milho. Faculdade de Ciências Agrárias e Veterinárias. Universidade Estadual Paulista, $105 \mathrm{p}$.

Freddi OS, Centurion JF, Beutler AN, Aratani RG, Leonel CL (2007a) Compactação do solo no crescimento radicular e produtividade da cultura do milho. R Bras Ci Solo. 31(4):627363.

Freddi OS, Centurion JF, Beutler NA, Aratani RG, Leonel CL, Silva AP (2007b) Compactação do solo e intervalo hídrico ótimo no crescimento e na produtividade da cultura do milho. Bragantia. 66(3):477-486.

Freddi OS, Centurion JF, Duarte AP, Leonel CL (2009a) Compactação do solo e produção de cultivares de milho em Latossolo Vermelho. I - Características de planta, solo e índice S. R Bras Ci Solo. 33(4):793-803.

Freddi OS, Centurion JF, Duarte AP, Peres FSC (2009b) Compactação do solo e produção de cultivares de milho em Latossolo Vermelho. II - Intervalo hídrico ótimo e sistema radicular. R Bras Ci Solo. 33(4):805-818.

Gonçalves WG, Severiano EC, Silva FG, Costa KAP, Guimarães Júnnyor WS, Melo GB (2014) Least limiting water range in assessing compaction in a Brazilian Cerrado Latosol growing sugarcane. R Bras Ci Solo. 38(2):432-443.

Kaiser DR, Reinert DJ, Reichert JM, Collares GL, Kunz M (2009) Intervalo hídrico ótimo no perfil explorado pelas raízes de feijoeiro em um Latossolo sob diferentes níveis de compactação. R Bras Ci Solo. 33(4):845-855.

Kichel NA, Costa JAA, Almeida RG (1 ed.) (2009) Cultivo simultâneo de capins com milho na safrinha: produção de grãos, de forragem e de palhada para plantio direto, Embrapa Gado de Corte, Campo Grande, 24 p.

Leão TP, Silva AP (2004) A simplified Excel algorithm for estimating the least limiting water range of soils. Sci Agric. 61(6):649-654.

Li S, Wu X, Liang G, Gao L, Wang B, Lu J, Abdelrhman AA, Song $X$, Zhang $M$, Zheng $F$, Degré $A$ (2020) Is least limiting water range a useful indicator of the impact of tillage management on maize yield? Soil Till Res. 199:104602.
Machado LAZ, Assis PGG (2010) Produção de palha e forragem por espécies anuais e perenes em sucessão à soja. Pesq Agropec Bras. 45(4):415-422.

Machado LAZ, Valle CB (2011) Desempenho agronômico de genótipos de capim braquiária em sucessão à soja. Pesq Agropec Bras. 46(11):1454-1462.

Maia GA, Costa KAP, Severiano EC, Epifânio PS, Flávio J Neto, Ribeiro MG, Fernandes PB, Silva JFG, Gonçalves WG (2014) Yield and chemical composition of Brachiaria forage grasses in the offseason after corn harvest. Am J Plant Sci. 5(5): 933941.

Pacheco LP, Pires FR, Monteiro FP, Procopio SO, Assis RL, Carmo ML, Petter FA (2008) Desempenho de plantas de cobertura em sobressemeadura na cultura da soja. Pesq Agropec Bras. 43(7):815-823.

Pioneer (2018) Resultados de produtividade. Disponível em: <http://www.pioneersementes.com.br/milho/central-deprodutos/resultados?typ=Milho\&campanha=Safrinha\&prod uto $=$ P3779H \& colheita $=2016 \&$ estado $=$ GO\&cidade $=$ Montividi u>. Accessed on: 29 April 2018.

Reichert JM, Suzuki LEAS, Reinert DJ (2007) Compactação do solo em sistemas agropecuários e florestais: Identificação, efeitos, limites críticos e mitigação In: Ceretta CA, Silva LS, Reichert JM (eds) Tópicos em ciência do solo. Viçosa: Sociedade Brasileira de Ciência do Solo, 5:49-134.

Santos HG, Jacomine PKT, Anjos LHC, Oliveira VA, Lumbreras, $J F$, Coelho MR, Almeida, JA, Araujo Filho KC, Oliveira JB, Cunha TJF (5 ed.) (2018) Sistema Brasileiro de Classificação de Solos. Embrapa, Brasília. Brasília: Embrapa Solos.

Severiano EC, Oliveira GC, Dias Junior MS, Curi N, Costa KAP, Carducci CE (2013) Preconsolidation pressure, soil water retention characteristics and texture of Latosols in the Brazilian Cerrado. Soil Res. 51(3):193-202.

Severiano EC, Oliveira GC, Dias Júnior MS, Costa KAP, Silva FG, Ferreira Filho SM (2011) Structural changes in Latosols of the Cerrado Region: I - relationships between soil physical properties and least limiting water range. $\mathrm{R}$ Bras $\mathrm{Ci}$ Solo. 35(3):773-782.

Silva AP, Imhoff S, Kay B (2004) Plant response to mechanical resistance and air-filled porosity of soils under conventional and no-tillage system. Sci Agric. 61(4):451-456.

Silva AP, Kay BD, Perfect E (1994) Characterization of the least limiting water range. Soil Sci Soc Am J. 58(6):1775-1781.

Sousa DMG, Lobato E (2004) Cerrado: correção do solo e adubação. Brasília: Embrapa Cerrados.

Teixeira PC, Donagemma GK, Fontana A, Teixeira, WG (eds.) (3 ed) (2017) Manual de métodos de análise de solo Brasília: Embrapa. 